\title{
Inhibitory Effect of 6,7-dimethoxy-5-hydroxyflavone on Human Cervix Carcinoma in Vitro
}

\author{
Ramazan ERENLER $^{* 1}$, Ibrahim DEMIRTAS ${ }^{2}$, Tunay KARAN ${ }^{3}$, Muhammed ALTUN², \\ Fatih GUL ${ }^{2}$
}

${ }^{1}$ Gaziosmanpasa University, Arts and Sciences Faculty, Department of Chemistry, 60240 Tokat

${ }^{2}$ Cankiri Karatekin University, Faculty of Sciences, Department of Chemistry, 18100 Cankiri, Turkey

${ }^{3}$ Gaziosmanpasa University, Arts and Sciences Faculty, Department of Biology, 60240 Tokat, Turkey

\section{Received: 04 May 2017 - Revised: 18 August 2017 - Accepted: 11 October 2017}

\begin{abstract}
Natural products derived from plants play a significant role in drug discovery due to the revealing a large variety of pharmaceutical effects. Kickxia spuriawas collected from Bingol, Turkey. Aerial parts of the plant were boiled in water for $2 \mathrm{~h}$ then extracted with ethyl acetate. After evaporation of the solvent by rotary evaporator, the extract was subjected to column chromatography to yield the compound identified as 6,7-dimethoxy-5hydroxyflavone by spectroscopic method including 1D-, 2D-NMR, LC-TOF/MS. Antiproliferative activity of isolated compound was tested against HeLa (human cervix carcinoma) cell lines by xCELLigence assay, and found out that the compound exhibited excellent activity.
\end{abstract}

Keywords: Kickxia spuria, flavone, HeLa

\section{INTRODUCTION}

Cancer, a destructive disease is a major public health burden in the world. Developments in the treatment of cancer have resulted in the notable improved survival and quality of life for cancer patients lately. The major treatments for cancer contain chemotherapy, surgery and radiation therapy [1]. Therapeutic strategies and new drugs are continuously being researched and developed, however current effect of chemotherapy is far from satisfactory. It is known that, prolonged chemotherapy treatment weakens the immunological defense system of the body and causes to other diseases to the patients. Accordingly, new approached should be developed for cancer treatment that have less side effects. Natural products derived from plants which have a strong activity against cancer cells could be an effective drugs for cancer treatment [2]. Natural products play a highly significant role in the drug discovery and development process. More than $60 \%$ of cancer drugs are natural origin [3]. Bioactive compounds isolated from plants have been used extensively in pharmaceutical, agrochemical, food and pesticide industries [4]. Kickxiabeloning to Scrophulariaceae family is comprised of about 47 species worldwide [5].

\footnotetext{
*Corresponding Author E-mail: rerenler@gmail.com
} 
Kickxiagenus belonging to Plantaginaceae family consisted of 47 species which were distributed throughout the Europe, Asia and Africa [6]. Kickxia species have been extensively used for traditional medicine to alleviate some diseases such as diuretic, against kidney stones, fever and rheumatism [7]. Phytochemical investigation on Kickxia genus resulted in the isolation of flavonoids and iridoid glycosides $[8,9]$.

In this work, 6,7-dimethoxy-5-hydroxyflavone was isolated from Kickxia spuria ethyl acetate extract and antiproliferative activity was investigated on HeLa (human cervix carcinoma) cell lines. The isolated compound revealed the outstanding effect on this cell lines.

\section{MATERIAL and METHODS}

\subsection{General experimental procedure}

A mass spectrum was recorded on a LC-TOF/MS spectrophotometer. NMR spectra were recorded on a spectrometer operation at $600 \mathrm{MHz}$ for ${ }^{1} \mathrm{H}$ and $150 \mathrm{MHz}$ for ${ }^{13} \mathrm{C}$ NMR. Chemical shifts were given in ppm $(\delta$ scale), coupling constant $(J)$ in Hz. Column chromatography was performed on silica (60-230 mesh, Merck). TLC was carried out on analytical alumina plates (60 F 254). Dulbecco's Modified Eagle's Medium High Glucose (DMEM), fetal bovine serum, streptomycin-penicillin were supplied from (Sigma, Germany).

\subsection{Plant material}

Kickxia spuriawas collected from Elazig, Baskil, 1000-1200 m, in 2012 Agust, Turkey and identified by Dr. LütfiBehçet. A voucher specimen was deposited in the Herbarium of the Faculty of Arts and Sciences, Bingol University (BIN 726).

\subsection{Extraction and isolation}

The areal parts $(0.5 \mathrm{~kg})$ of the plant material were dried and then boiled in water. After filtration of the solid part, the solvent was extracted with ethyl acetate. Solvent was removed by rotary evaporator to yield the crude extract $(0.2 \mathrm{~g})$ which was subjected to silica gel column chromatography, eluted with hexane, hexane/EtOAc, EtOAc, EtOAc/MeOH, MeOH to yield the title compound. The structure was identified by spectroscopic methods including 1D-NMR, 2D-NMR and LC-TOF/MS and comparison of these values with the literature [10]. ${ }^{1} \mathrm{H}$ NMR $\left(600 \mathrm{MHz}, \mathrm{CDCl}_{3}\right) \delta 12.68(1 \mathrm{H}, s, 5-\mathrm{OH}), 7.90\left(2 \mathrm{H}, d, J=7.4 \mathrm{~Hz} 2^{\prime}-\mathrm{H}, 6{ }^{\prime}-\mathrm{H}\right), 7.54\left(2 \mathrm{H}, m, 3^{\prime}-\right.$ $\mathrm{H}, 6$ '-H) $7.53\left(1 \mathrm{H}, m, 4\right.$ '-H), $6.68(1 \mathrm{H}, s, 3-\mathrm{H}), 6.57(1 \mathrm{H}, s, 8-\mathrm{H}), 3.98\left(3 \mathrm{H}, s, 7-\mathrm{OCH}_{3}\right) 3.93$ $\left(3 \mathrm{H}, s, 6-\mathrm{OCH}_{3}\right) .{ }^{13} \mathrm{C}$ NMR $\left(150 \mathrm{MHz}, \mathrm{CDCl}_{3}\right) \delta 182.72(\mathrm{C}-4), 163.95(\mathrm{C}-2), 158.90(\mathrm{C}-7)$, 153.33 (C-8), 153.05 (C-4), 132,73 (C-6),131.81 (C-2'), 126.24 (C-9), 106.32 (C-10), 105.64 (C-3), $90.63(\mathrm{C}-8), 60.85\left(\mathrm{OCH}_{3}-6\right), 56.32\left(\mathrm{OCH}_{3}-7\right)$.

\subsection{Cell lines and cell culture}

HeLa cancer cell lines were grown in Dulbecco's modified eagle medium (DMEM) supplemented with $10 \%$ fetal bovine serum, $2 \%$ penicillin streptomycin. The medium was changed twice a week [11].

\subsection{Cell profileration assay}

The Real Time Cell Analyzer-Single Plate (RTCA-SP, xCELLigence) instrument (Roche Applied Science, Basel, Switzerland) was used to visualize the antiproliferative effects of the isolated compound on human cervical cancer (HeLa) cells. RTCA-SP is a combination of four parts: an E-Plate 96, a Single Plate (SP) station that is kept in an incubator and holds the EPlate 96, an analyzer and a computer with RTCA software. The E-Plate 96 wells have an inner volume of $243 \mu \mathrm{L}$ and their bottoms are coated with golden electrodes. The xCELLigencemeasures impedance differences set by an operator in order to derive cell index values at time points and impedance differences as well as the cell index values depends on the 
cell activity at the bottom of the wells. The higher cell index value depends on the higher the cell population growing at the bottom and the greater the spreading of the cells. RTCA allows researchers to analyze cell behavior in a labeling-free cell-based assay and produces a real-time profile of the cells [12].

\section{RESULTS and DISCUSSIONS}

In this work, 6,7-dimethoxy-5-hydroxyflavone was isolated. The structure was identified by spectroscopic method including 1D-, 2D-NMR, LC-TOF/MS. Antiproliferative effect was investigated on HeLa cell lines and was demonstrated to have excellent antiproliferative activity (Figure 1).

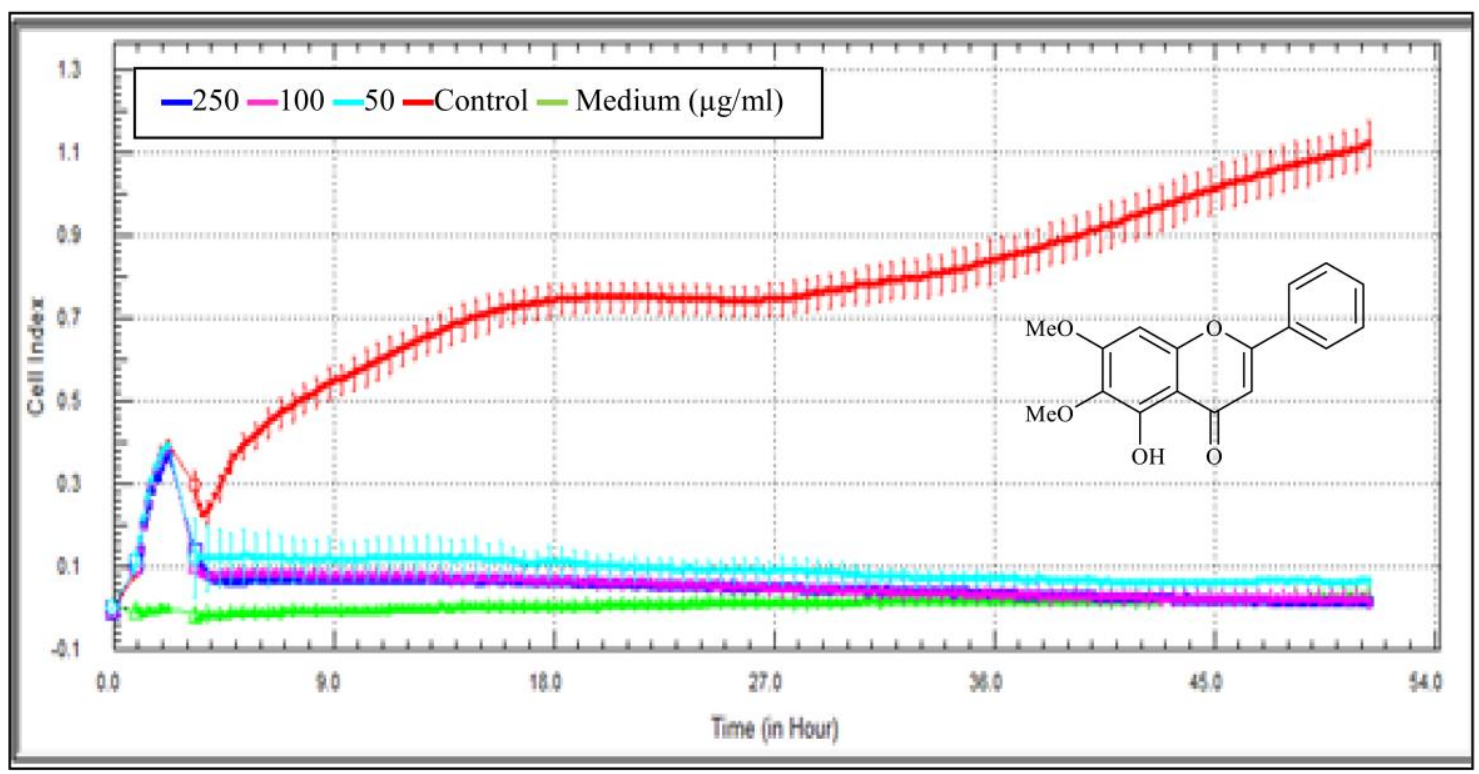

Figure 1. Antiproliferative effect of 6,7-dimethoxy-5-hydroxyflavone on HeLa cell lines

Flavonoids are one of the most common polyphenols, and they exhibit interesting and beneficial medicinal and pharmaceutical effects [13-16]. The various biological properties of flavonoids, such as antioxidant, antiinflammatory, anticancer, antibacterial, immunestimulating and antiviral activities, have been reported extensively [17]. Polarity is an important consideration for extraction methods. Less polar flavonoids (e.g., isoflavones, flavanones, methylated flavones, and flavonols) are extracted with chloroform, dichloromethane, diethyl ether, or ethyl acetate, while flavonoid glycosides and more polar aglycones are extracted with alcohols or alcohol-water mixtures. Glycosides have increased water solubility and aqueous alcoholic solutions are suitable. The bulk of extractions of flavonoid-containing material are still performed by simple direct solvent extraction[18]. Cancer is the lead of the illness causing to the death. Side effects of the synthetic chemotherapy medicines accelerated the investigation of effectiveness of the secondary metabolites against to the cancer. The aim of new anticancer drugs is to eradicate the cancer cells without damaging the normal cells. Natural products are effective class of medicine used against to the cancer. Among these natural products, podophyllotoxin, etoposide, teniposide are used clinically to treat cancer[19] .

\section{CONCLUSION}

Due to the significance of natural products in cancer treatment, isolation of antiproliferative compounds from plants gained the great interest. Kickxia spuria has a potency to be a drug against cancer. Pharmaceutically and medicinally valuable compound, 6,7dimethoxy-5-hydroxyflavone was isolated from Kickxia spuria by chromatographic methods and the structure was elucidated by spectroscopic techniques. This compound revealed the 
excellent antiproliferative activity against HeLa (human cervix carcinoma) cell lines. Hence, further phytochemical and biological screening should be carried out to present the usage of this species in pharmaceutical and medicinal industries.

\section{Conflict of Interests}

Authors declare that there is no conflict of interests.

\section{REFERENCES}

[1]. Jhanwar, Y.S., \& Divgi, C. (2005). Current status of therapy of solid tumors. Journal of Nuclear Medicine, 46(1): 141S-50S.

[2]. Patel, D., Shukla, S., \& Gupta, S. (2007). Apigenin and cancer chemoprevention: progress, potential and promise. International Journal of Oncology, 30(1): 233-45.

[3]. Newman, D.J., Cragg, G.M., \& Snader, K.M. (2003). Natural products as sources of new drugs over the period 1981-2002. Journal of Natural Products, 66(7): 1022-37.

[4]. Newman, D.J., \& Cragg, G.M. (2007). Natural products as sources of new drugs over the last 25 years. Journal of Natural Products, 70(3): 461-77.

[5]. Davis, P.H. Flora of Turkey and The East Aegean Islands. University Press, Edinburgh (1978).

[6]. Khan, I., \& Aqil, M. (1993). Isolation and identification of pectolinarin and mannitol from Kickxia ramosissima (Wall). Chemical and Environmental Research, 2(3): 287-89.

[7]. Amin, A., Tuenter, E., Foubert, K., Iqbal, J., Cos, P., Maes, L., et al. (2017). In vitro and in silico antidiabetic and antimicrobial evaluation of constituents from Kickxia ramosissima (Nanorrhinum ramosissimum). Frontiers in Pharmacology, 8: 1-12.

[8]. Singh, M., \& Prakash, L. (1987). A New Flavone Glycoside and Other ChemicalConstituents from Kickxia Ramosissima Wall - (Scrophulariaceae). Pharmazie, 42(7): 490-91.

[9]. Al-Rehaily, A.J., Abdel-Kader, M.S., Ahmad, M.S., \& Mossa, J.S. (2006). Iridoid glucosides from Kickxia abhaica D.A Sutton from Scrophulariaceae. Phytochemistry, 67(5): 429-32.

[10]. Ghani, N.A., Ahmat, N., Ismail, N.H., \& Zakaria, I. (2011). Flavonoid constituents from the stem bark of polyalthia cauliflora var. Cauliflora. Australian Journal of Basic and Applied Sciences, 5(8): 154-58.

[11]. Erenler, R., Meral, B., Sen, O., Elmastas, M., Aydin, A., Eminagaoglu, O., et al. (2017). Bioassay-guided isolation, identification of compounds from Origanum rotundifolium and investigation of their antiproliferative and antioxidant activities. Pharmaceutical Biology, 55(1): 1646-53.

[12]. Erenler, R., Sen, O., Aksit, H., Demirtas, I., Yaglioglu, A.S., Elmastas, M., et al. (2016). Isolation and identification of chemical constituents from Origanum majorana and investigation of antiproliferative and antioxidant activities. Journal of the Science of Food and Agriculture, 96(3): 822-36.

[13]. Demirtas, I., Erenler, R., Elmastas, M., \& Goktasoglu, A. (2013). Studies on the antioxidant potential of flavones of Allium vineale isolated from its water-soluble fraction. Food Chemistry, 136(1): 34-40.

[14]. Elmastas, M., Erenler, R., Isnac, B., Aksit, H., Sen, O., Genc, N., et al. (2016). Isolation and identification of a new neo-clerodane diterpenoid from Teucrium chamaedrys $\mathrm{L}$. Natural Product Research, 30(3): 299-304. 
[15]. Erenler, R., Yilmaz, S., Aksit, H., Sen, O., Genc, N., Elmastas, M., et al. (2014). Antioxidant Activities of Chemical Constituents Isolated from Echinops orientalis Trauv. Records of Natural Products, 8(1): 32-36.

[16]. Erenler, R., Telci, I., Ulutas, M., Demirtas, I., Gul, F., Elmastas, M., et al. (2015). Chemical Constituents, Quantitative Analysis and Antioxidant Activities of Echinacea purpurea (L.) Moench and Echinacea pallida (Nutt.) Nutt. Journal of Food Biochemistry, 39(5): 622-30.

[17]. Harborne, J.B., \& Williams, C.A. (2000). Advances in flavonoid research since 1992. Phytochemistry, 55(6): 481-504.

[18]. Harborne, J.B., \& Williams, C.A. (1995). Anthocyanins and Other Flavonoids. Natural Product Reports, 12(6): 639-57.

[19]. Nicolaou, K.C., Hepworth, D., King, N.P., \& Finlay, M.R.V. (1999). Chemistry, biology and medicine of selected tubulin polymerizing agents. Pure and Applied Chemistry, 71(6): 989-97. 